\title{
VALIDITAS BUKU PETUNJUK PRAKTIKUM BIOLOGI DASAR BERBASIS PEMECAHAN MASALAH UNTUK MAHASISWA PENDIDIKAN IPA DI UNIVERSITAS WIRARAJA
}

\author{
Dyah Ayu Fajarianingtyas $^{1}$, Jefri Nur Hidayat ${ }^{2}$ \\ Universitas Wiraraja ${ }^{1,2}$ \\ Azrilarkan@gmail.com ${ }^{1}$, jefri.nh@wiraraja.ac.id ${ }^{2}$
}

\begin{abstract}
ABSTRAK
Pendekatan pembelajaran yang dapat membangun literasi sains mahasiswa dapat menggunakan pembelajaran berbasis masalah. Pembelajaran berbasis masalah sejalan dengan tujuan membangun literasi sains peserta didik (Abidin, Mulyani, \& Yunansah, 2018). Tujuan penelitian adalah (1) apakah buku petunjuk praktikum Biologi Dasar berbasis pemecahan masalah yang dikembangkan valid sebagai buku petunjuk praktikum; dan (2) bagaimana tingkat keterbacaan buku petunjuk praktikum Biologi Dasar berbasis pemecahan masalah. Subjek penelitian adalah mahasiswa Biologi Dasar. Metode penelitian yang digunakan adalah $R \& D$ dengan model penelitian pengembangan yang dikembangkan oleh (Thiagarajan, Semmel, \& Semmel, 1974) yaitu 4D. Penelitian ini menggunakan tahapan (Define) Pendefinisian; (Design) Perancangan dan (Develop) pengembangan. Data validitas buku petunjuk praktikum diperoleh dari hasil penilaian ahli desain dan ahli materi. Data tingkat keterbacaan buku petunjuk praktikum diukur menggunakan tes klos (tes rumpang). Hasil penelitian bahwa (1) buku petunjuk praktikum berbasis pemecahan masalah valid berdasarkan nilai validasi materi sebesar 94\% (kategori baik) dan validasi desain sebesar 90\% (kategori baik). Artinya ada kesesuaian buku petunjuk praktikum Biologi dasar dengan tujuan praktikum dan kesesuaian kalimat pada buku petunjuk praktikum berdasarkan EBI; (2) hasil uji keterbacaan buku petunjuk praktikum berbasis pemecahan masalah 100\%. Artinya ada buku petunjuk praktikum yang dikembangkan dalam kategori mudah dipahami oleh mahasiswa.
\end{abstract}

Kata Kunci: Buku petunjuk praktikum berbasis pemecahan masalah.

\begin{abstract}
Learning approaches that can build student scientific literacy can use problem-based learning. Problem-based learning is in line with the goal of building students' scientific literacy (Abidin, Mulyani, \& Yunansah, 2018). The research objectives are (1) whether the basic Biology based practical work guide for problem solving developed is valid as a practical manual; and (2) how the level of readability of the Basic Biology practicum based on problem solving. Research subjects were students of Basic Biology. The research method used $R \& D$ with a development research model developed by (Thiagarajan, Semmel, \& Semmel, 1974), namely 4D. This research uses Define stages; (Design) Design and (Develop) development. The validity data of the practicum manual was obtained from the results of the design expert and material expert assessment. Data readability level practicum guide is measured using a toilet test (mortar test). The results of the study that (1) manual based on problem solving valid valid based on the material validation value of $94 \%$ (good category) and design validation of $90 \%$ (good category). This means that there is a compatibility of the basic Biology practical manual with the purpose of the practicum and the suitability of the sentence in the practical manual based on the EBI; (2) the readability test results for practicum based on 100\% problem solving. This means that there are practical manuals developed in the category easily understood by students.
\end{abstract}

Keywords: Problem-based practical guide book 


\section{PENDAHULUAN}

Penguasaan sains dan teknologi menjadi kunci keberhasilan suatu bangsa dalam memasuki abad ke-21. Pendidikan sains berperan penting dalam menghasilkan mahasiswa yang memiliki kemampuan logis, kreatif, berpikir kritis, inovatif, serta berdaya saing global. Keterampilan literasi sains dibutuhkan dalam era digital saat ini karena permasalahan berkaitan dengan pengetahuan dan teknologi serta memberdayakan masyarakat untuk membuat keputusan individu dan berpartisipasi merumuskan kebijakan publik yang berdampak pada kehidupan mereka (Abidin et al., 2018).

Pembelajaran berbasis masalah (PBM) menjadi salah satu pendekatan pembelajaran yang membangun literasi mahasiswa. Pembelajaran aktif ini memungkinkan mahasiswa untuk sadar dan memiliki kemampuan pemecahan masalah, untuk belajar mengenai belajar, mampu menggunakan pengetahuan secara operasional, dan melakukan kerja kelompok pada konteks permasalahan kehidupan nyata. Pembelajaran berbasis masalah sejalan dengan tujuan membangun literasi sains peserta didik (Abidin et al., 2018). Peran dosen dalam proses belajar mengajar adalah menyajikan masalah, mengajukan pertanyaan dan memfasilitasi penyelidikan. PBM dapat merangsang berpikir tingkat tinggi dalam situasi berorientasi masalah termasuk di dalamnya belajar bagaimana belajar. (Arend, 2012).

Berdasarkan capaian pembelajaran matakuliah Biologi Umum terutama pada capaian bahwa mahasiswa harus dapat menguasai konsep-konsep dasar keilmuan yang mencerminkan kemampuan memformulasikan penyelesaian masalah secara prosedural, maka peneliti merancang suatu inovasi pembelajaran yaitu mengembangkan petunjuk praktikum berbasis pemecahan masalah. Hasil observasi didapatkan fakta bahwa petunjuk praktikum mata kuliah Biologi Umum tahun akademik 2018 yang ada di kampus Cemara belum optimal melatih mahasiswa IPA berorientasi terhadap pemecahan masalah. Fakta ini juga ditunjukkan pada kegiatan diskusi dosen, maka mahasiswa cenderung belajar menghafal teoritis tanpa diterapkan dalam kehidupan sehari-hari. Hasil respon mahasiswa tahun 2018 juga menyatakan bahwa dosen kurang mengupdate materi yang berorientasi terhadap pemecahan masalah.

Petunjuk Praktikum Berbasis Masalah Sebagai Penunjang Kemampuan Keterampilan Proses Sains dalam Pembelajaran Literasi Sains dapat menjadi salah satu solusi mengatasi permasalahan di Prodi Pendidikan IPA kampus cemara. Berdasarkan hasil penelitian Fauziah (2018) pengembangan produk penuntun praktikum biologi umum dengan nilai 3,50 berbasis pendekatan saintifik dikategorikan sangat valid. hasil penelitian Wahyuni (2015) Pengembangan buku petunjuk praktikum IPA yang dikembangkan cukup efektif dalam meningkatkan kemampuan berpikir kritis siswa dalam kategori layak.

Penelitian ini memiliki rumusan masalah sebagai berikut: Apakah buku petunjuk praktikum Biologi Dasar berbasis pemecahan masalah yang dikembangkan valid sebagai buku petunjuk praktikum? Bagaimana tingkat keterbacaan buku petunjuk praktikum Biologi Dasar berbasis pemecahan masalah?

\section{METODE PENELITIAN}

Penelitian ini menggunakan Research and Development. Model penelitian yang digunakan adalah model penelitian pengembangan yang dikembangkan oleh (Thiagarajan et al., 1974) yaitu 4D (four D) ditunjukkan pada Gambar 3.1. Fokus model pengembangan 4D yaitu dalam bidang pendidikan. Model pengembangan 4D terdiri dari 4 tahap yaitu: Define (mendefinisikan), Design (merancang), 
Develope (mengembangkan), dan Disseminate (menyebarkan).

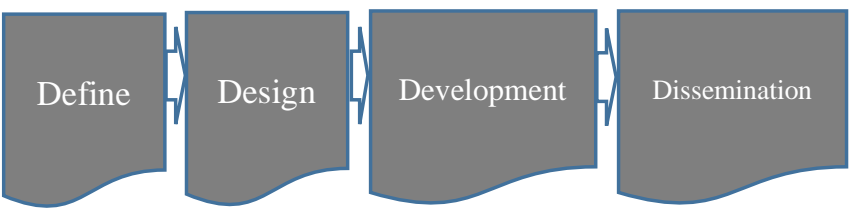

Gambar 3.1. Tahapan penelitian dan pengembangan model 4D

(Thiagarajan et al., 1974)

Penelitian ini sampai pada tahap ketiga yaitu Develope. Langkah-langkah penelitian ditunjukkan pada gambar 3.2.

\section{Tahap Pendefinisian (Define)}

Prosedur pertama pada penelitian ini adalah tahap pendefinisian dimana memiliki tujuan dalam penentuan kebutuhan dalam pembelajaran serta untuk mengumpulkan berbagai informasi agar dapat mengatasi permasalahan yang ada. Thiagarajan, Semmel, dan Semmel (Rochmad, 2012) menyatakan bahwa tahap pendefinisian dilakukan dengan cara: (1) lakukan Analisis kegiatan awal-akhir (front-end analysis), (2) Penganalisisan pada siswa (Learner Analysis), (3) Analisis tentang tugas (Task analysis), (4) Analisis mengenai Konsep (Concept analysis), dan (5) Spesifikasi khsusus (Specifying instructioal).

2. Tahap Perancangan (Design)

Tahap kedua pada penelitian ini yaitu melakukan untuk merancang buku petunjuk praktikum yang dikembangkan.

3. Tahap Pengembangan (Develop)

Tahap pengembangan dilakukan setelah melalui revisi berdasarkan masukan dari ahli materi maupun desain. Langkah yang dilakukan pada tahap ini yaitu: Validasi oleh ahli (Expert Appraisal). Hasil uji pengembangan meliputi uji validitas dan uji keterbacaan.

\section{A. Subjek Uji Coba}

Populasi menggunakan semua mahasiswa yang menempuh mata kuliah Biologi Dasar tahun akademik 2019-2020.

\section{B. Tempat Penelitian}

Penelitian dan pengembangan ini dilakukan di Program Studi Pendidikan IPA Fakultas Keguruan dan Ilmu Pendidikan (FKIP) Universitas Wiraraja.

\section{Waktu Penelitian}

Penelitian ini dilaksanakan pada bulan April sampai Oktober 2019.

\section{Jenis Data}

Penelitian ini memperoleh data kualitatif dan kuantitatif. Data kualitatif dari komentar validator untuk perbaikan dan penyempurnaan produk. Data kuantitatif diperoleh dari skor penilaian validator dan skor uji keterbacaan.

\section{E. Instrumen Pengumpulan Data}

Bentuk instrument penelitian terdiri atas lembar validasi petunjuk praktikum dan lembar uji keterbacaan.

1. Lembar Validasi buku petunjuk praktikum

Data diperoleh dari hasil penilaian ahli desain dan ahli materi. Data tersebut sebagai acuan dan pedoman merevisi serta mengembangkan produk yang telah dibuat.

2. Lembar Uji Keterbacaan

Dilakukan untuk mengetahui hubungan antara pembaca dengan teks yang dibaca mengenai petunjuk praktikum yang dikembangkan.

\section{F. Teknik Analisis Data}

Berupa analisis validasi produk dan uji keterbacaan materi.

1. Analisis Validasi Produk 
Aspek yang dianalisis pada produk meliputi komponen validasi materi dan komponen validasi desain. Kriteria validasi produk dapat dilihat pada Tabel 3.1.

Persentas $=\frac{\text { Jumlah }(\text { Jawaban } \times \text { Bobot setiap pilihan })}{N \times \text { Bobot tertinggi }} \times 100$ $\%$

Kriteria validasi dapat dilihat pada Tabel berikut ini.

Tabel 3.1. Kualifikasi penilaian Buku Petunjuk Praktikum

\begin{tabular}{ccc}
\hline $\begin{array}{c}\text { Tingkat } \\
\text { pencapaian }\end{array}$ & Kualifikasi & Keterangan \\
\hline$>80 \%$ & Sangat Baik & $\begin{array}{c}\text { Tidak perlu } \\
\text { direvisi }\end{array}$ \\
\hline $70 \%-79 \%$ & Baik & $\begin{array}{c}\text { Tidak perlu } \\
\text { direvisi }\end{array}$ \\
\hline $60 \%-69 \%$ & Cukup & Direvisi \\
\hline $50 \%-59 \%$ & Kurang & Direvisi \\
\hline$<50 \%$ & $\begin{array}{c}\text { Sangat } \\
\text { Kurang }\end{array}$ & Direvisi \\
\hline
\end{tabular}

\section{Uji Keterbacaan Materi}

Uji keterbacaan penelitian ini menggunakan Tes klos. Tes ini digunakan untuk mengukur kemampuan membaca. Teknik tes klos ialah prosedur peraturan yang dapat digunakan dalam peringkat pembahasan isi serta struktur yang dikemukakan dalam kalimat, makna, dan keterbacaan. Teknik ini dapat digunakan sebagai alat pengukur tingkat keterbacaan teks bacaan/wacana. (Damaianti, 1991).

Strategi tes klos dilakukan dengan pelesapan/penghapusan kata pada sebuah teks wacana, yaitu dengan:

1) melihat dari jumlah kata ke-n (dipilih pada jarak yang tetap, variasi penghapusan, mulai dari tiap kata ke-5 s.d. kata ke-10 (Farr dan Rossser, 1979)

2) melihat dari pemilihan kata secara selektif atau secara random, John (1977) menghapus setiap kata sifat yang ke-10, Rhodes (1972) menghilangkan kata kerja yang ke-
10. Penghapusan secara random dilakukan tanpa melihat hubungan kontekstual atau jenis kata tertentu (Jongsma, 1980).

Penilaian teknik klos dilakukan dengan melihat hasil persentase. Rankin dan Culhane (dalam (Damaianti, 1991) menetapkan bahwa sebuah teks wacana dikatakan mudah apabila persentase skor tes mencapai $>60 \%$, teks wacana dikatakan sedang apabila persentase skor tes antara 41\%-60\%, dan teks wacana dikatakan sukar apabila skor tesnya $<40 \%$.

\section{HASIL}

Buku petunjuk praktikum Biologi dasar berbasis pemecahan masalah dirancang sebagai penunjang keterampilan sains dalam proses pembelajaran literasi. Data hasil penelitian dan pengembangan ini sebagai berikut.

\section{Tahapan Define}

Pada tahap (a) analisis kegiatan awalakhir (front-end analysis) didapatkan fakta bahwa petunjuk praktikum mata kuliah Biologi Umum tahun akademik 2018 yang ada di kampus Cemara belum optimal melatih mahasiswa IPA berorientasi terhadap pemecahan masalah; pada kegiatan diskusi dosen, ada kecenderungan mahasiswa belajar menghafal teoritis tanpa diterapkan dalam kehidupan sehari-hari; dan respon mahasiswa tahun 2018 juga menyatakan bahwa dosen kurang mengupdate materi yang berorientasi terhadap pemecahan masalah. Pada tahap (b) Penganalisisan pada siswa (Learner Analysis) mendapatkan data bahwa mahasiswa Biologi dasar di kampus Cemara dalam kategori dewasa awal yaitu memiliki kemampuan untuk mendefinisikan masalah dengan memasukkan ke dalam kategori tertentu untuk masalah logis dan menyusun definisi mengenai cakupan masalah tersebut. Tahapan (c) analisis tentang tugas (Task 
analysis) didapatkan bahwa tugas Biologi dasar belum berorientasi terhadap pemecahan masalah. Tahapan (d) analisis mengenai Konsep (Concept analysis) bahwa konsep materi fotosintesis dan respirasi pada mata kuliah Biologi Dasar berorientasi terhadap kemampuan mahasiswa untuk menyelesaikan masalah. Tahap (d) Spesifikasi khsusus (Specifying instructioal) diperoleh data bahwa tujuan pembelajaran menguasai konsep dasar keilmuan yang mencerminkan kemampuan memformulasikan penyelesaian masalah secara prosedural.

\section{Tahapan Design}

Data yang diperoleh pada tahapan ini meliputi perumusan masalah yang berkaitan dengan objek yang relevan dengan materi praktikum. Hasil desain penelitian ini yaitu petunjuk praktikum berbasis masalah yang terdiri atas (a) fokus kajian masalah; (b) tujuan; (c) konsep kunci; (d) petunjuk; (e) informasi pendukung; (f) cek pengetahuan; (g) ayo buktikan; (h) penilaian; dan (i) daftar pustaka. Fokus kajian masalah menyajikan masalah autentik yang relevan dengan materi praktikum; tujuan memuat tujuan praktikum yaitu penyelesaian masalah secara procedural; konsep kunci berisi point penting materi praktikum; petunjuk menyajikan aturan penggunaan buku petunjuk praktikum berbasis masalah; informasi pendukung berisi hasil riset yang relevan dengan materi fotosintesis dan respirasi; cek pengetahuan memuat materi praktikum yang disajikan secara singkat dan jelas berdasarkan literatur; ayo buktikan memuat langkah-langkah praktikum untuk pemecahan masalah yang telah disajikan pada fitur focus kajian masalah; penilaian memuat soal uraian yang menunjan pengetahuan mahasiswa; dan daftar pustaka berisi literature yang digunakan dalam penyusunan buku petunjuk praktikum berbasis masalah.

\section{Tahapan Develop}

Pada tahapan ini telah dilakukan pengembangan buku petunjuk praktikum berbasis pemecahan masalah dan diperoleh data bahwa hasil uji validasi telah dilakukan oleh validator sebagai berikut pada Tabel 4.1.

Tabel 4.1 Daftar nama validator buku Petunjuk Praktikum berbasis Pemecahan Masalah

\begin{tabular}{ccc}
\hline No. & \multicolumn{1}{c}{ Nama Validator } & $\begin{array}{c}\text { Bidang } \\
\text { Keahlian }\end{array}$ \\
\hline \multicolumn{3}{c}{ Ahli Materi } \\
\hline 1. & $\begin{array}{l}\text { Dr. Ericka Darmawan, } \\
\text { S.Si, M.Pd }\end{array}$ & $\begin{array}{c}\text { Pendidikan } \\
\text { Biologi }\end{array}$ \\
\hline \multicolumn{3}{c}{ Ahli Desain } \\
2. & $\begin{array}{l}\text { Dr. Abbassyakhrin, } \\
\text { M.Pd }\end{array}$ & $\begin{array}{c}\text { Teknologi } \\
\text { Pendidikan }\end{array}$ \\
\hline
\end{tabular}

Hasil uji validasi materi dapat ditunjukkan pada Tabel 4.2 berikut ini.

\section{Tabel 4.2. Ringkasan Hasil Validasi} Materi

\begin{tabular}{clc}
\hline No & Kriteria Penilaian & $\begin{array}{c}\text { Rata-rata } \\
\text { Persentase }\end{array}$ \\
\hline 1 & Tujuan pembelajaran & 4,5 \\
\hline 2 & $\begin{array}{l}\text { Terdapat koherensi } \\
\text { antara tujuan } \\
\text { praktikum dengan } \\
\text { paparan materi }\end{array}$ & 5 \\
\hline 3 & $\begin{array}{l}\text { Materi praktikum } \\
\text { memuat pemecahan } \\
\text { masalah }\end{array}$ \\
\hline & $\begin{array}{l}\text { Materi buku petunjuk } \\
\text { praktikum yang } \\
\text { disajikan akurat dan } \\
\text { kontekstual }\end{array}$ & 5 \\
\hline 5 & $\begin{array}{l}\text { Susunan dan urutan } \\
\text { materi praktikum jelas } \\
\text { dan logis }\end{array}$ & 5 \\
\hline 6 & $\begin{array}{l}\text { Eksperimen praktikum } \\
\text { mendorong } \\
\text { mahasiswa paham } \\
\text { konsep }\end{array}$ \\
\hline 7 & $\begin{array}{l}\text { Kesesuaian isi buku } \\
\text { petunjuk praktikum }\end{array}$ & 5 \\
\hline
\end{tabular}




\begin{tabular}{clc}
\hline \multicolumn{2}{c}{$\begin{array}{l}\text { dengan tingkat } \\
\text { pendidikan }\end{array}$} & \\
\hline 8 & $\begin{array}{l}\text { Kesesuaian penilaian } \\
\text { dengan materi }\end{array}$ & 4,5 \\
\hline 9 & $\begin{array}{l}\text { Kesesuaian gambar } \\
\text { dengan materi } \\
\text { praktikum } \\
\text { Kemudahan } \\
\text { penggunaan buku } \\
\text { praktikum }\end{array}$ & 5 \\
\hline 11 & $\begin{array}{l}\text { Kemudahan } \\
\text { penggunaan bahasa }\end{array}$ & 5 \\
\hline 12 & $\begin{array}{l}\text { Ketepatan tata bahasa } \\
\text { dan ejaan }\end{array}$ & 5 \\
\hline & Jumlah & 56,5 \\
\hline & Persentase & $94 \%$ \\
\hline Kategori & Sangat Baik \\
\hline
\end{tabular}

Hasil uji validasi desain dapat ditunjukkan pada Tabel 4.3 berikut ini.

Tabel 4.3 Hasil validasi Desain buku Petunjuk Praktikum berbasis Masalah

\begin{tabular}{clc}
\hline No & Kriteria Penilaian & $\begin{array}{c}\text { Rata-rata } \\
\text { Persentase }\end{array}$ \\
\hline 1 & Kualitas Penjilidan & 4 \\
\hline 2 & Desain sampul & 4 \\
\hline 3 & Layout pengetikan & 5 \\
\hline 4 & Identitas teks & 3,5 \\
\hline 5 & Variasi penyajian & 5 \\
\hline 6 & Daftar isi & 5 \\
\hline 7 & Daftar Rujukan & 5 \\
\hline & Jumlah & 31,5 \\
\hline & Persentase & $90 \%$ \\
\hline & Kategori & Sangat Baik \\
\hline
\end{tabular}

Hasil uji keterbacaan buku Petunjuk Praktikum berbasis Masalah dapat ditunjukkan pada Tabel 4.4 berikut ini.

Tabel 4.4 Hasil uji keterbacaan buku Petunjuk Praktikum berbasis Masalah

\begin{tabular}{clc}
\hline No & \multicolumn{1}{c}{ Materi } & $\begin{array}{c}\text { Hasil } \\
\text { Penilaian }\end{array}$ \\
\hline 1 & Fotosintesis & $100 \%$ \\
\hline 2 & Respirasi Seluler & $100 \%$ \\
\hline
\end{tabular}

\section{PEMBAHASAN}

1. Validitas Buku Petunjuk Praktikum Biologi Dasar Berbasis Pemecahan Masalah

Hasil uji validasi materi sebesar $94 \%$ (kategori baik). Hasil validasi menunjukkan bahwa landasan materi pada buku petunjuk praktikum telah sesuai dengan kegiatan praktikum sehingga tujuan praktikum dapat tercapai. Penilaian tahap satu mendapatkan saran dan masukan dari validator materi bidang keahlian Pendidikan Biologi sehingga dilakukan revisi. Adapun revisi yang dilakukan adalah permasalahan atau fenomena real yang ada dalam kehidupan sehari-hari sehingga masalah tidak muncul secara teoritis.

Hal ini sesuai dengan yang dinyatakan (Arikunto, 2005) bahwa jika sebuah data yang dihasilkan dari sebuah produk valid, maka dapat dikatakan produk yang dikembangkan telah memberikan gambaran tentang tujuan pengembangan secara benar dan sesuai dengan kenyataan dan keadaan sesungguhnya. Aspek materi buku petunjuk praktikum biologi dasar pemecahan masalah dinyatakan valid karena telah dilengkapi dengan fitur (a) fokus kajian masalah yang membimbing mahasiswa untuk mencari permasalahan yang autentik; (b) tujuan pembelajaran yang membimbing mahasiswa untuk memikirkan apa yang mereka dapatkan dari pembelajaran; (c) konsep kunci yang membimbing mahasiswa untuk memikirkan apa yang mereka dapatkan dari pembelajaran; (d) petunjuk penggunanan buku praktikum yang membimbing mahasiswa untuk melakukan percobaan; (e) informasi pendukung yang membimbing mahasiswa untuk mengkonstruksi pengetahuan dari riset; (f) cek pengetahuan yang membimbing mahasiswa untuk berdiskusi; (g) ayo buktikan yang membimbing mahasiswa mengumpulkan data dan menganalisis 
sehingga ditemukan solusi dari masalah yang diteliti; (h) penilaian yang membimbing mahasiswa untuk menjawab pertanyaan dan membuat kesimpulan berdasarkan percobaan; dan (i) daftar pustaka yang membimbing mahasiswa menelusuri sumber belajar.

Buku petunjuk praktikum yang dikembangkan juga berbasis pemecahan masalah yang ada di fitur fokus kajian masalah. Pada fitur ini disajikan masalah autentik pada materi fotosintesis dan respirasi seluler. Keterampilan belajar dan berinovasi yang meliputi berpikir kritis dan mengatasi masalah harus dikuasai mahasiswa dalam pembelajaran abad ke-21 (Drs Daryanto, Drs Syaiful Karim, 2017). Hal ini sesuai dengan (Arend, 2012) menyatakan bahwa penggabungan pelajaran dengan isu dari sebuah masalah dalam kehidupan sehari-hari ini mampu membantu mahasiswa dalam menghasilkan pemecahan yang tepat dari masalah tersebut. Mahasiswa dituntut untuk mengambil keputusan pemecahan masalah diantara beberapa alternatif yang ditemukan. Pembelajaran pemecahan masalah merupakan pendekatan yang sangat efektif untuk mengajarkan proses berpikir tingkat tinggi, membantu mahasiswa memproses informasi yang telah dimilikinya, dan membangun mahasiswa membangun sendiri pengetahuannya tentang dunia social dan fisik di sekelilingnya (Priansa, 2017).

Pendekatan pembelajaran yang dapat membangun literasi sains mahasiswa dapat menggunakan pembelajaran berbasis masalah. Pembelajaran ini merupakan pembelajaran aktif yang mengajak mahasiswa untuk melatih kemampuan problem solving, untuk belajar mengenai belajar, mampu menggunakan pengetahuan secara operasional, dan melakukan kerja kelompok pada konteks permasalahan kehidupan nyata. Pembelajaran berbasis masalah sejalan dengan tujuan membangun literasi sains peserta didik (Abidin et al., 2018). Hasil penelitian (Rahayu, Sapri, \& Alexon, 2017) bahwa terdapat peningkatan berpikir kritis yang belajar dengan model Problem Based Learning (PBL).

Hasil uji validasi desain sebesar $90 \%$ (kategori baik). Hasil validasi menunjukkan bahwa kalimat pada buku petunjuk praktikum telah sesuai dengan ejaan bahasa Indonesia. Menurut (Hamdani, 2011) menyatakan bahwa aspek bahasa merupakan salah satu aspek yang perlu diperhatikan dalam penyusunan bahan ajar, bahasa yang digunakan sebaiknya bahasa yang sederhana dan mudah dipahami. Buku petunjuk praktikum biologi dasar berbasis pendekatan pemecahan masalah memberikan manfaat bagi mahasiswa dalam melaksanakan kegiatan praktikum. Hal ini dapat membantu mahasiswa mengembangkan sikap keterampilan mahasiswa dalam memecahkan permasalahan serta dalam mengambil keputusan secara objektif dan mandiri (Priansa, 2017).

\section{Keterbacaan Buku Petunjuk Praktikum Biologi Dasar Berbasis Pemecahan Masalah}

Hasil analisis diperoleh persentase skor keterbacaan sebesar $100 \%$. Berdasarkan kriteria, maka buku petunjuk praktikum yang dikembangkan dalam kategori mudah dipahami oleh mahasiswa. Tingkat keterbacaan buku petunjuk praktikum diukur menggunakan tes klos (tes rumpang). Tes klos berupa bacaan yang telah dihilangkan beberapa bagian kata sehingga menjadi rumpang. Pengisian bagian yang rumpang dapat memunculkan aktivitas membaca secara alamiah dan normal yang disebut keterbacaan (Kurnia, Sugianto, \& Marwoto, 2017).

Berdasarkan Tabel 4.4 skor keterbacaan tinggi karena penyajian buku petunjuk praktikum menggunakan bahasa yang sesuai dengan taraf kemampuan 
mahasiswa, mudah dipahami, dan memiliki struktur kalimat yang jelas. Selain itu, penulisan teks pada buku petunjuk praktikum menggunakan jenis dan ukuran huruf yang disesuaikan dengan aturan tipografi. Hal ini sesuai dengan hasil penelitian (Suryadi, 2007) menyatakan bahwa tingkat keterbacaan dipengaruhi oleh faktor bahasa yang menyangkut pilihan kata, susunan kalimat, dan unsur tata bahasa yang lain. Faktor rupa juga berpengaruh yang mencakup tata huruf (tipografi) terdiri atas jenis dan ukuran huruf, kerapatan baris, dan unsur tata rupa lain.

\section{KESIMPULAN}

1. Buku petunjuk praktikum berbasis pemecahan masalah valid berdasarkan nilai validasi materi sebesar $94 \%$ (kategori baik) dan validasi desain sebesar 90\% (kategori baik). Artinya ada kesesuaian buku petunjuk praktikum Biologi dasar dengan tujuan praktikum dan kesesuaian kalimat pada buku petunjuk praktikum berdasarkan EBI.

2. Hasil uji keterbacaan buku petunjuk praktikum berbasis pemecahan masalah 100\%. Artinya ada buku petunjuk praktikum yang dikembangkan dalam kategori mudah dipahami oleh mahasiswa.

\section{DAFTAR PUSTAKA}

Abidin, Mulyani, Y., \& Yunansah, T. (2018). PEMBELAJARAN LITERASI: Strategi Meningkatkan Kemampuan Literasi Matematika, Sains, Membaca, dan Menulis. Jakarta: Bumi Aksara.

Aqil, D. I. (2017). Literasi Sains sebagai Konsep Pembelajaran Buku Ajar Biologi di Sekolah. Wacana Didaktika Jurnal Pemikiran, Penelitian Pendidikan Dan Sains, 5(2), 160-171.
Arend, I. R. (2012). Learning to Teach. New York: Mc Graw-Hill.

Arikunto, S. (2005). Dasar-Dasar Evaluasi Pendidikan: Bumi Aksara. Jakarta.

Budiarti, W., \& Oka, A. A. (2014). Pengembangan Petunjuk Praktikum Biologi Berbasis Pendekatan Ilmiah (Scientific Approach) Untuk Siswa SMA Kelas XI Semester Genap Tahun Pelajaran 2013/2014. BIOEDUKASI Jurnal Pendidikan Biologi, 5(2), 123-130.

Budiningsih, T. Y., Rusilowati, A., \& Marwoto, P. (2015). Pengembangan Buku Ajar IPA Terpadu Berorientasi Literasi Sains Materi Energi dan Suhu. Journal of Innovative Science Education, 4(2), 34-40.

Damaianti, V. S. (1991). Teknik Klos sebagai Alat Ukur dalam Menentukan Kesangkilan Wacana Bahasa Indonesia. Skripsi, Tidak Diterbitkan). Bandung FPBS IKIP.

Drs Daryanto, Drs Syaiful Karim, M. . (2017). Pembelajaran Abad 21. In Pembelajaran Abad 21. Yogyakarta.

Fauziah, N. (2018). Validitas Penuntun Praktikum Biologi Umum Berbasis Pendekatan Saintifik untuk Mahasiswa. Indonesian Biologi Teachers, 1(2), 42-45.

Hamdani, S. B. M. (2011). Bandung: CV. Pustaka Setia.

Kurnia, W. H., Sugianto, S., \& Marwoto, P. (2017). LKS BERBASIS MULTIPLE INTELLIGENCES DALAM PEMBELAJARAN IPA FISIKA DI SEKOLAH MENENGAH PERTAMA. UPEJ Unnes Physics Education Journal, 6(1), 9-15.

Nengsi, S. (2016). Pengembangan Penuntun Praktikum Biologi Umum Berbasis Inkuiri Terbimbing Mahasiswa Biologi STKIP Payakumbuh. JURNAL IPTEKS TERAPAN, 10(1), 47-55. 
https://doi.org/http://dx.doi.org/10.22

216/jit.2016.v10i1.343

Prastowo, A. (2011). Panduan Kreatif Membuat Bahan Ajar. Jogjakarta: Diva Press.

Priansa, D. J. (2017). Pengembangan Strategi dan Model Pembelajaran. Bandung: CV Pustaka Setia.

Rahayu, S., Sapri, J., \& Alexon, A. (2017). The Implementation of Problem Based Learning $(\mathrm{Pbl})$ for Improving Critical Thinking and Student's Achievement. Jurnal Ilmiah Teknologi Pendidikan, 7(2), 98-110.

Rochmad. (2012). Desain Model Pengembangan Perangkat Pembelajaran Matematika. Jurnal Kreano, 3(1), 59-72.

Sumarli, Murdani, E., \& Wijaya, A. K. (2017). Pengembangan Buku Petunjuk Praktikum Fisika : Pengujian Jenis Kawat Konduktor Komersial. Jurnal Ilmu Pendidikan Fisika, 2(2), 30-34.

Suryadi, A. (2007). Tingkat keterbacaan wacana sains dengan teknik klos. Jurnal Sosioteknologi, 6(10), 196200.

Thiagarajan, S., Semmel, D. S., \& Semmel, M. I. (1974). Instructional Development for Training Teachers of Exceptional Children: A Sourcebook. In ERIC. Indiana: ERIC.

Trianto. (2012). Model Pembelajaran Terpadu. Jakarta: Bumi Aksara.

Wahyuni, S. (2015). Pengembangan Petunjuk Praktikum IPA untuk Meningkatkan Kemampuan Berpikir Kritis Siswa SMP. Jurnal Pengajaran MIPA, 20(2), 196-203. https://doi.org/http://dx.doi.org/10.18 269/jpmipa.v20i2.585 